\title{
Institutional Innovation in Zakah Management: The Experience of Putukrejo Village, Indonesia
}

\author{
Supranoto \\ Lecturer in Faculty of Social and Political Sciences \\ University of Jember \\ supranoto.fisip@gmail.com
}

\author{
Moh. Zaini BinAbu Bakar \\ Lecturer in School of Social Sciences \\ Universiti Sains Malaysia \\ zainiab@usm.my
}

\author{
Moh. Zahri Bin Hamat \\ Lecturer in School of Islamic Development Studies \\ Universiti Sains Malaysia zahri@usm.my
}

\begin{abstract}
This article aims to describe the experience of Putukrejo, a village in Indonesia, which develop innovative institution to manage zakah. Zakah is philantropical action that is obligated for every muslim. Zakah can be paid directly by the obligated individual to another individual eligible for zakah. Distribution pattern like this provoke a lot of problems. Aside from direct distribution, zakah can be paid collectively and indirectly. People pay their zakah to certain institutions. This certain institution then distributed zakah to parties that is eligible to receive. What choice is picked by Putukrejo's citizens and how to organize it and also the result? This article is made to answer those questions from institutional perspective.
\end{abstract}

Key words-institution; zakah; collective action;collaborative management;Putukrejo Village

\section{INTRODUCTION}

The south areas of Malang regency had suffered from drought because of long dry season in 1964. It made farmers, the majority in these areas, had suffered crop failure. The next impact was easy to be guessed, which was the poverty level raised dramatically.[1]

Putukrejo village faced a really complex dilemma. Located in south area of Malang regency, Putukrejo village was not spared from drought. In addition to that disaster, Putukrejo village also faced another "disaster" that was faced by many villages in Indonesia. In those past years, a national political situation was through tremendous tension because of seized power competition and the influence between TNI AD, PKI, and (President) Soekarno. This conflict spread into citizens. In consequence, the economy was lack of concern thus cause massive poverty everywhere. In other words, wherever the citizens were, they can't rely on government's helping hand.

In that situation, Putukrejo village turned to philanthropic action that is obligated for muslims which was zakah. They started organize management of zakah as collective action at village level and reached their success in the 1970s until 1980 s decade. In frame of run the determination to overcome acute poverty problem that hit the village, Putukrejo village developed an institution innovation to manage the zakah by focusing on two things, which were (a) effective collaboration between three pillars of society, namely Umara', Ulama', and Aghniya',[2] and (b) effective rules of the game that enabling the collaboration can be run effectively.

\section{ThreE Kinds Of InSTRUCTION ON ZAKAH}

In terminologies, zakah is some part of wealth that is given by its owner to other residents that have the rights to receive it. There are three kinds of command about zakah in Al-Quran. First, command to muslim individual to pay zakah. This is for example can be seen in this postulate

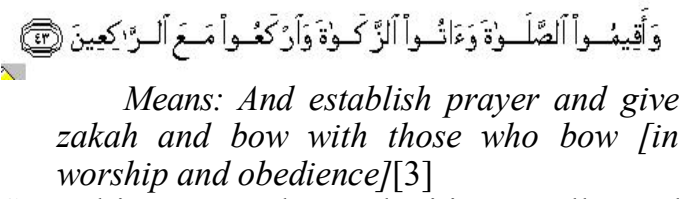

Second is command to authorities to collect zakah. This command is equivalent to command from government to collect tax from citizens. Zakah is indeed having strong social character, as well as to mustahik (zakah receiver) and muzakki (zakah giver). Along with the command to collect zakah, to the authorities[4] is also commanded to pray for them who already paid zakah as what this partial said.

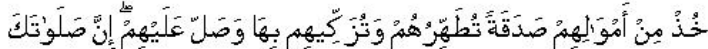

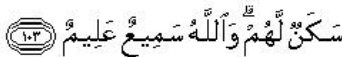

$$
\begin{aligned}
& \text { Means: "Take charity from their }
\end{aligned}
$$

Third is command for zakah maintainers to distribute those zakah to eight groups that is having the right to receive zakah. The word "maintainers" on the last sentence can mean individual zakah payer or institution that is given, or founded to perform, duty to manage zakah. Social character or 
philanthropist out from zakah command can also be seen from eight asnaf groups as ordered by Al-Quran in this partial.

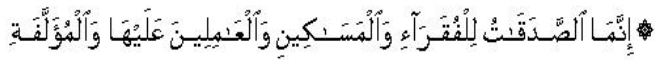

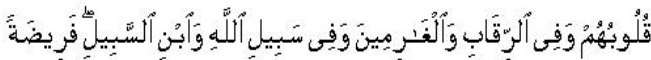

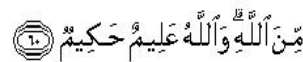

Means: Charities are only for the poor and the needy, and those employed to collect them, and those whose hearts are to be reconciled, and for [the freedom of] the slaves and the debtors, and in the way of Allah, and for the traveller. [This is] an ordinance from Allah, and Allah is allknowing, all-wise. [6]

In summary, it can be told that commands about zakah consist of three kinds, which are command (to every muslim) to pay zakah, command (to authorities) to collect zakah, and command (to individual and maintainers) to distribute zakah. Three Quran commands about zakah above are upheld theoretically by among these two perspectives. These two perspectives underlined the importance of using zakah to overcome poverty. The first is presented by Habib Ahmed who persuades to contemplate and consider a slightly different strategy, which is by developing zakah institution as what this partial said.

Though there have been some progress in reducing poverty in a few countries, there is now emerging consensus that many development programs aimed at poverty reduction in the past have not achieved their intended results in many parts of the world. There is, therefore, a need to seek credible programs and strategies that can effectively mitigate poverty. In this regard, one of the important pillars of combating poverty in Muslim societies is the institution of zakah. Zakah along with other charitable institutions emerged as a result of specific emphasis of Islam on meeting the needs of less privileged members of the society. Early Islamic history demonstrates this charitable institution to be very effective in taking care of the needy sections of the population in Muslim societies. Narrations from the time of Umar bin al Khattab $(13-22 \mathrm{H})$ and Umar bin Abdul Aziz $(99-101 \mathrm{H})$ indicate that poverty was eliminated during the time of these two rulers, as zakah collected in some regions could not be disbursed due to lack of poor recipients.[7]

The perspective of Ahmed Habib regarding how important zakah to economic and overcome poverty also underlined by these two, Nasim Shah Shirazi and Md. Fouad Bin Amin. They stated, "Half of the sample countries not only meet their resource shortfall by potential zakat collection but also generate surplus funds which are sufficient for the resource deficit countries."[8]

The interesting question to be answered is what are institutional options that are available to execute those three commands? This question will be answered by this section.

\section{TWO KINDS OF INSTITUION IN ZAKAH} MANAGEMENT AND PUTUKREJO INNOVATION

Even though the concept of instituion has historical rooted until 1725[9], but the meaning of instituion until now is always confusing to the concept of organization. Without intending to avoid the definitional debate, this article uses the definition of North stating that the institution is the constraints that were created according to levels of human ability that is used to establish and facilitate human interaction[10]. Institutions are the rules that govern the relationships between people and another person in a community, and between members of a community with parties in other communities. This rule can be writtenly or not. Scope setting a rule could be measuring the neighborhood relations, can also be an area of the village, district, province, country, and even across the country.

Zakat is obligatory on every Muslim. The fulfillment of this obligation can be done individually, that is distributed directly by muzakki (giving alms) to mustahik (recipients), including in particular the poor and needy. But can also be the fulfillment of the obligation of zakat is done through collective action.[11] The village Putukrejo experience in managing zakat is a manifestation of collective action in addressing the worship of the individual and social worship. Collective action is one of the types of institutions in the provision of various types of goods and services human purposes. Collective action can be done at the international level, countries, and even can also be at the village or community, even in groups of two (dyadic).[12] McLain (1991) wrote that among the four types of coordination in the provision of goods and services, market and the state are two forms of coordination of the most controversial and the most contentious. [13]

The village Putukrejo options to manage zakat collectively in the decade of the 1970s was a very innovative institutional choice for several reasons. First, this is the right choice for treating the management of zakat as an individual act contains several drawbacks, namely (a) creates a gap zakat, (b) create imbalances collection / polling, (c) creates inequality of distribution, (d) meenimbulkan safety hazards, and (e) the inaccuracies in the recording so it is difficult to justify.

Secondly, at that time, the Government of Indonesia chose to hand over the management of zakat to setiapp individuals in society. This means that the state does not want to intervene care charity affairs. Manage zakat collectively as did the Village Putukrejo because it is a decision that is very innovative. In 1999., the Indonesian government decided to treat the management of zakat as though collective action but allows zakat individually.

How Desa Putukrejo run their choice to manage the charity as a collective action? Zakat management activities as a collective action involving three parties, namely Muzakki (Giving Zakat), Mustahik (Receiver Zakat), and business Zakat (Zakat). Zakat is the connecting Muzakki with Mustahik. The role of Zakat is run done collectively in the village Putukrejo. To that end, they did it by involving the three pillars of the society as mentioned earlier, namely Umara '(Government), Ulama' (Civil Society), and Aghniya 
'(Employers'). The pattern of their relationship can be described as follows.

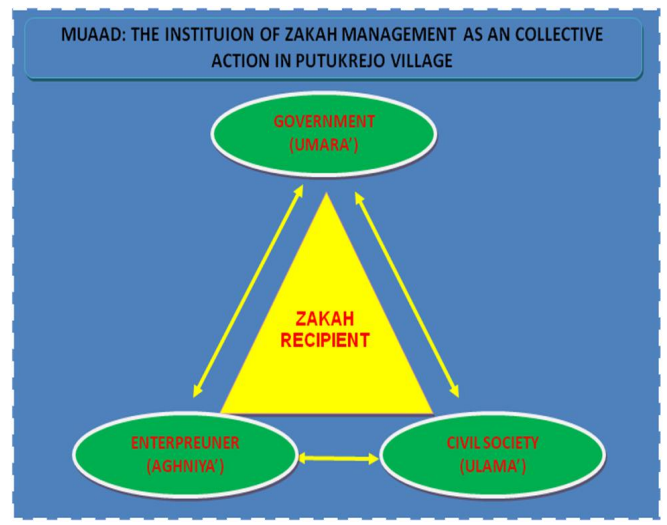

Figure1. Collaborative Relation between Umara' (Government), Ulama' (Civil Society), and Aghniya' (Enterpreuner) in Zakah Management in Putukrejo Village

\section{REFERENCES}

[1]Yamin Haddad, 2004 and Zainuri, 2010.

[2]In public administration terminology nowadays, this three pillars collaboration is called with the term of governance. Three pillars of governance includes Government, Civil Society, and Corporate World. It is equivalent to, respectively, Umara' , Ulama' , Aghniya'

[3]QS Al-Baqarah [2]: 43. Command to pay zakah lie around in Al-Quran, most of it superimposed by command to shalat such as, among what is noted by Prof. Dr. KH. Fathurrahman Rauf in his treatise themed

"Zakat Dalam Pusaran Dinamika Sosial Keumatan: Mewujudkan 'Good Zakat Governance' ", foreword for the book entitled Zakat untuk Pengentasan Kemiskinan, created by H.M. Subki Risya, PP. LAZIS NU, Jakarta, 2009. At page viii, that foreword mentions that "....in al-Qur' an can be found at least 72 times "zakat" terminology is mentioned that is carried out together with "shalat" word $\cdots$, implementation of zakah precept has the same primacy with shalat precept in Islam."

[4]It was believed that command " collect" aimed to Rasulullah SAW. After the days of Rasulullah, this zakah collector is amil zakat who in muslim is appointed to government. Look at for example Masdar F. Mas' udi, opcit., Prof. Dr. KH. Sjechul Hadi Permono, SH., MA., opcit.
[5] QS At-Taubah [9]: 103.

[6]QS At-Taubah [9]: 60. Look at also QS Al-Hasyr [59]: 7 ( $\cdots$ " so that they do not circulate among the rich among you $\cdots "$ )

[7]Professor Habib Ahmed, PhD. 2011. Opcit: 81-82.

[8]Nasim Shah Shirazi and Md. Fouad Bin Amin, Prospects of Poverty Elimination Through Potential Zakat Collection in OIC-Member Countries: Reappraised, Journal of Islamic Economics, Banking and finance, Volume 6 Number 3, 2010.

[9]Geoffrey M.Hodson. 2006. What Are Institutions? Journal of Economic Issues, Vol. XL No. 1, March 2006.

[10]Douglas C. North, 1990a: 182; North 1990b: 3

[11]Ini sejalan dengan pandangan yang mengatakan bahwa kewajiban membayar zakat adalah ibadah individual sekaligus ibadah sosial. Lihat, sebagai contoh, A. Muhtadi Anshor, Kewajiban Zakat dan Pajak Dalam Perspektif Islam, Jurnal AHKAM, Volume 11, Nomor 2, November 2009: 135-140. Dua sifat kewajiban ini (individual dan sosial) juga diisyaratkan oleh Suhaili Sarif and Nor 'Azzah Kamri. Dalam artikel mereka bertajuk A Theoritical Discussion of Zakat for Income Generation and Its Fiqh Issues yang dimuat di Shariah Journal, Vol. 17, No. 3 (2009) 457-500 mereka mengatakan "This is due to the fact that the zakat as religious obligation must accordingly adhere to the principles underlined by shari' ah beside any other economic objective which it strives to achieve." Lihat juga Prof. Dr. KH. Fathurrahman Rauf, opcit: ix.

[12]E.S. Savas (1989) noted ten institutional arrangement to providing goods and services.

[13]Iain McLain. 1991. Public Choice. New York: Basil Blackwell. Dua yang lain adalah anarchy dan voluntaristic action. Sebagai pembanding, dapat juga dilihat Savas, E.S. 1987. Privatization: The Key to Better Government. Chatham, New Jersey: Chatham House Publishers, Inc.; Olson, Mancur. 1965. The Logic of Collective Action: Public Goods and the Theory of Groups. Cambridge: Harvard University Press; Ostrom and Ostrom Ostrom, V dan E.Ostrom [1977] 1999. “Public Goods and Public Choice” . Dalam Michael D. McGinnis. Polycentricity and Local Public Economies. Readings from the Workshop in Political Theory and Policy Analysis. Ann Arbor: The University of Michigan Press. Hal. 87-99; Ostrom, Elinor. 1990. Governing the Commons, The Evolution of Institutions for Collective Action. Cambridge: Cambridge Univ. Press. 